\title{
Proteolysis-Targeting Chimeras (PROTACs) Based on Macrocyclic Tetrapeptides Selectively Degrade Class I Histone Deacetylases 1-3
}

Martin Roatsch,,$^{\dagger}$ Anja Vogelmann, ${ }^{\dagger,+}$ Daniel Herp,,+ Manfred Jung, ${ }^{+}$Christian A. Olsen ${ }^{\dagger, *}$

${ }^{\dagger}$ Center for Biopharmaceuticals \& Department of Drug Design and Pharmacology, Faculty of Health and Medical Sciences, University of Copenhagen, Universitetsparken 2, 2100

Copenhagen, Denmark

$\$$ Institute for Pharmaceutical Sciences, Albert-Ludwigs-University Freiburg, Albertstraße 25, 79104 Freiburg i.Br., Germany 


\section{ABSTRACT}

Histone deacetylases (HDACs) remove acetyl groups from histone proteins and are implicated in gene regulation. They have been recognized as drug targets for treatment of cancer and other human diseases and several inhibitors are already clinically used. Here, we report the design, synthesis, and cellular characterization of a proteolysis-targeting chimera (PROTAC) capable of selectively degrading class I HDACs $1-3$ in cells. These novel chemotypes are based on potent and class I-selective macrocyclic tetrapeptide inhibitors, which were linked to thalidomide by modular synthesis, employing copper-catalyzed azide-alkyne "click" chemistry. In HEK293T cells, these conjugates lead to degradation of HDAC1-3 in a time- and concentration-dependent manner. Concomitant histone hyperacetylation without leading to cytotoxic effects was observed by western blot. These chemotypes enable the study of the biological roles of class I HDAC enzymes by short-term temporal deletion. Our compounds represent the first examples of degraders with demonstrated selectivity for class I HDACs 1-3. Importantly, this study highlights the utility of cyclic peptides as target-binding elements for PROTAC design in general.

KEYWORDS: PROTAC $\bullet$ histone deacetylase $\bullet$ macrocyclic peptides $\bullet$ protein degradation $\bullet$ epigenetics 


\section{INTRODUCTION}

Posttranslational modification of histone proteins, ${ }^{1}$ around which DNA is wrapped in eukaryotic cells, has been recognized as a vital part of epigenetic regulation, which controls gene expression. One important and highly dynamic posttranslational modification (PTM) is the acetylation of lysine side chains, which is introduced by histone acetyl transferases (HATs) and removed by histone deacetylases (HDACs). ${ }^{2}$ Two fundamentally different groups of HDACs are known. The sirtuins (SIRT1-7, class III) remove acyl groups via an $\mathrm{NAD}^{+}$-dependent mechanism, ${ }^{3}$ while the 11-member family of histone deacetylases (HDAC1-11) are $\mathrm{Zn}^{2+}$-dependent hydrolases. ${ }^{2,4}$ Based on their sequence similarity, HDACs can be grouped into different classes: class I (HDAC1, 2, 3, and 8), class IIa (HDAC4, 5, 7, and 9), class IIb (HDAC6 and 10), and class IV (HDAC11). ${ }^{5-7}$ The HDACs 1-3 primarily exhibit activity as members of multiprotein complexes, including CoREST, Sin3, and NuRD for HDACs 1 and 2, while HDAC3 associates with proteins such as NCoR and SMRT. ${ }^{8-10}$ Dysregulation of histone deacetylation has been associated with the manifestation of severe diseases, including cancer, neurological diseases, and immune disorders. ${ }^{11-12}$ Therefore, inhibition of HDACs has been the subject of numerous drug discovery efforts in industry and academia alike and several potent inhibitors have been reported to date. ${ }^{13}$ Three small molecule inhibitors and one disulfide bridge-containing depsipeptide have received FDA approval and numerous additional compounds are under clinical investigation, while one additional small molecule (chidamide) has been approved for clinical use in China (Figure 1). ${ }^{14-15}$ All these chemotypes generally follow a zinc-binding group-linker-cap group pharmacophore, where the zinc-binding group (ZBG) coordinates to the conserved $\mathrm{Zn}^{2+}$ ion present in active sites of all eleven HDACs. ${ }^{14,16}$ The extended linker typically mimics the acetylated lysine side chain of a histone substrate, protruding into the active site, while the cap group binds to the surface of the HDAC 
protein. One distinct class of HDAC inhibitors are macrocyclic peptide inhibitors, such as apicidin, trapoxin, and the family of azumamides, ${ }^{17-21}$ featuring zinc-binding groups like ethylketone, epoxyketone, or carboxylic acid and carboxamide, respectively. These are generally believed to be weaker zinc binders than the hydroxamic acid or $o$-aminobenzamide found in the clinically approved small molecules (Figure 1). ${ }^{17}, 22$ However, the peptide macrocycles contribute significantly to the binding affinity, to afford potent inhibitors of class I HDACs with inhibition constants ( $K_{\mathrm{i}}$ values) in the low nanomolar range.

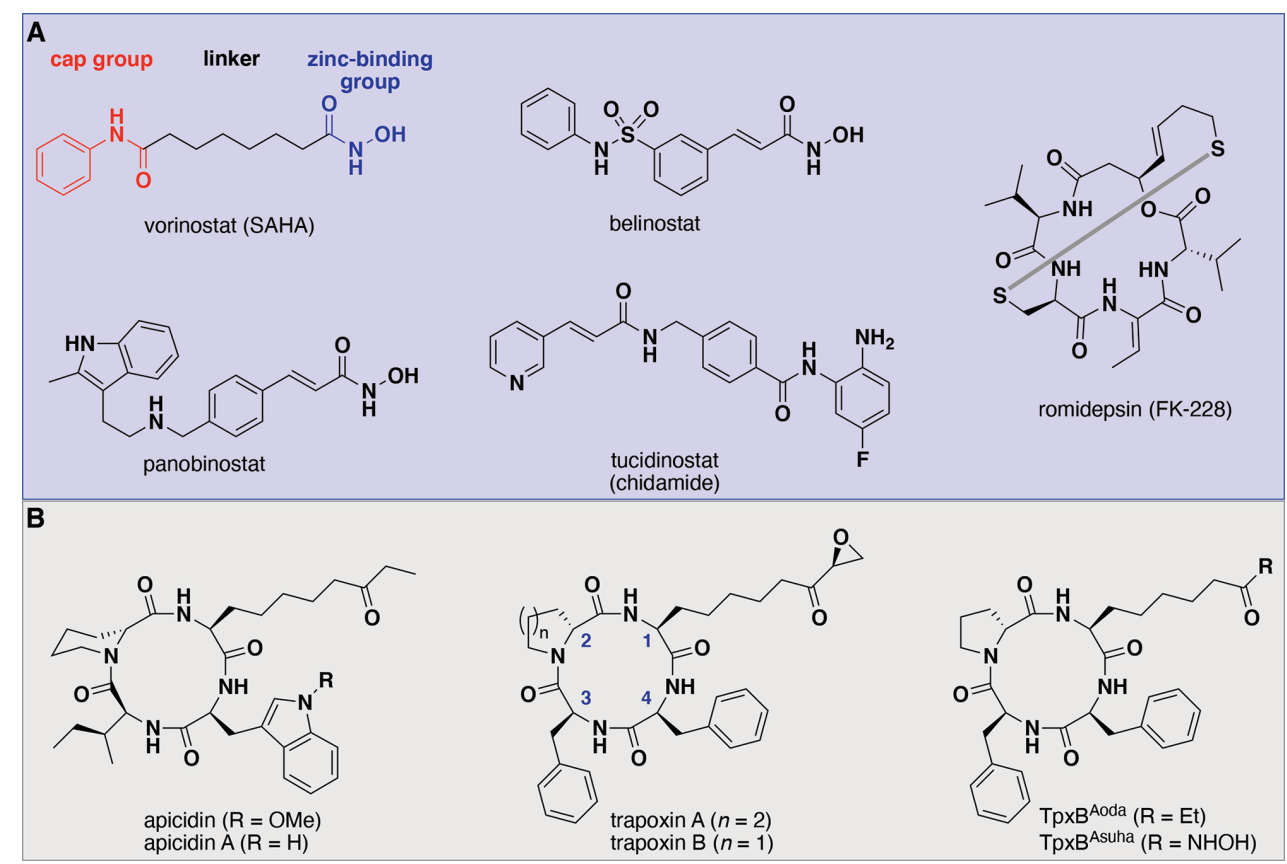

Figure 1. Chemical structures of selected HDAC inhibitors. (A) Clinically approved HDAC inhibitors vorinostat, panobinostat, belinostat, chidamide, and romidepsin. The zinc binding group-linker-cap group pharmacophore is highlighted in color code for vorinostat. (B) Naturally occurring macrocyclic peptide inhibitors apicidin, apicidin $\mathrm{A}$, trapoxin $\mathrm{A}$, and trapoxin $\mathrm{B}$ and their synthetic derivatives $\mathrm{TpxB}^{\mathrm{Aoda}}$ and $\mathrm{TpxB}^{\text {Asuha }}$. Amino acid numbering for the macrocycles is based on trapoxins (numbers shown in blue).

Recently, the new paradigm of developing "protein degraders" or so-called PROteolysisTArgeting Chimeras (PROTACs) has attracted significant attention in the field of medicinal chemistry. These bifunctional compounds contain a binding motif for a protein of interest and, 
connected via a linker moiety, a recognition motif for an E3 ubiquitin ligase. By bringing the ubiquitin ligase and the protein of interest into close proximity, these molecules trigger polyubiquitination of the protein of interest and subsequent degradation by the proteasome, the inherent protein degradation machinery of the cell. Such protein degraders, if based on reversible binders, are in principle catalytic and can lead to degradation of several copies of the target protein. This, in theory, requires lower cellular concentrations of the compound, compared to traditional drug substances, and reduces the risk of adverse off-target effects. ${ }^{23}$ Moreover, potentially "undruggable" proteins can also be targeted as long as a motif for transient binding to the protein of interest is available, including binders of allosteric sites. Since its original description in $2001,{ }^{24}$ the development of PROTACs has received wide attention ${ }^{25-32}$ and has been applied to several targets, including kinases, ${ }^{23,33-36}$ androgen ${ }^{37-38}$ and estrogen receptors, ${ }^{23,} 39$ bromodomains, ${ }^{40-44}$ a G-protein coupled receptor, ${ }^{45}$ signal transducers and activators of transcription, ${ }^{46-47}$ and even selfdegradation of ubiquitin ligases. ${ }^{48}$ The utility of PROTACs in chemical biology investigations was recently highlighted by elucidating the biological functions of a kinase, independent of its enzymatic activity. ${ }^{49}$ In a recent report, targeting of one protein in the polycomb repressor complex for degradation led to concomitant degradation of other proteins in the complex, an observation termed "collateral ubiquitination". 50

Although constituting a highly promising new strategy for drug discovery, the first examples of resistance development against PROTACs have recently been documented, usually involving cellular changes to the ubiquitin transfer machinery. ${ }^{51-52}$

Development of degraders of PTM-erasing enzymes has so far been limited to sirtuin $2^{53}$ and HDAC6, with the latter being targeted both using an unselective HDAC inhibitor ${ }^{54}$ and the HDAC6-selective inhibitor nexturastat A. ${ }^{55-58}$ During the preparation of this manuscript, another 
group also reported degraders of class I HDACs derived from aminobenzamide-based inhibitors (vide infra). ${ }^{59}$

Here, we report the design, synthesis, and biochemical characterization of selective degraders of class I HDACs 1-3, suitable for the study of the effects of temporal HDAC deletion, without overall cytotoxicity. These novel chemotypes are based on macrocyclic tetrapeptide HDAC inhibitors, constituting the first examples of PROTACs based on a macrocyclic peptide targetbinding scaffold.

\section{RESULTS}

Compound Design and Synthesis. For our degraders targeting class I HDACs, we envisioned linking macrocyclic HDAC inhibitors to the E3 ligase recruiter thalidomide. This structure recruits the E3 ligase cereblon $(\mathrm{CRBN})$ and - together with the closely related phthalimide-based immunomodulatory imide drugs (IMiDs) lenalidomide and pomalidomide - constitutes one of the most commonly used recruiting elements in the PROTAC field. ${ }^{33-34,41-42,45-48,53-57,59-60}$ Applying a previously established clickable thalidomide-azide building block, ${ }^{53}$ we envisioned a facile modular synthesis by incorporation of alkyne-bearing side chains into the macrocyclic tetrapeptides, followed by "click" chemistry to assemble the bifunctional target molecules. We chose a trapoxin-inspired scaffold for the backbone. Informed by previously established structureactivity relationship (SAR) derived from macrocyclic HDAC inhibitors, where the amino acid in position 1 carries the zinc-binding group, position 2 is D-proline or D-pipecolic acid, and where position 4 should contain a (bulky) aromatic residue, ${ }^{17-18,20}$ we chose the amino acid at position 3 as the attachment point for thalidomide, via $\mathrm{Cu}(\mathrm{I})$-catalyzed Huisgen [3+2] azide-alkyne cycloaddition $^{61-62}$ (see Figure 1 for numbering). Alkynes were incorporated by use of the non- 
canonical amino acid L-propargylglycine (L-Prg) and propargylated tyrosine building blocks ( $\mathbf{S 3}$ and S6, Scheme S1), providing extended distance from the macrocycle. For the zinc-binding group, we incorporated both a strong zinc binder, hydroxamic acid, as well as a weaker zinc binder, ethyl ketone. This small series of compounds would allow us to address both the effect of linker length and zinc-binding strength simultaneously.

A protected form of (S)-2-amino-8-oxodecanoic acid (Boc-L-Aoda-OMe S12b, Scheme S1C) was synthesized by adapting an established procedure ${ }^{63}$ For the ethyl ketone derivatives, the linear tetrapeptides were synthesized manually in solution by iterative Boc deprotection with TFA and HATU-mediated peptide coupling. The individual intermediate peptides were purified by column chromatography. While this is a somewhat tedious approach, it afforded the linear tetrapeptides in high purity for subsequent deprotection and macrocyclization (Scheme S2A). The crude cyclic peptides bearing an alkyne moiety were then subjected to the "click" conjugation of the thalidomide-azide building block using established conditions (Scheme S3) ${ }^{53}$ Purification by preparative HPLC afforded the ethyl ketone-containing PROTACs $\mathbf{1}$ and $\mathbf{2}$ in good yield and high purity (Figure 2).

The hydroxamate-containing precursors were synthesized by applying an Fmoc protected, O-tert-butyl-hydroxamic acid-containing building block (Fmoc-L-Asu ${ }^{(\mathrm{NHO} t \mathrm{Bu})}-\mathrm{OH}$ S15, Scheme S2B), which was available from a previous investigation. ${ }^{64}$ Here, the syntheses of the linear tetrapeptides were achieved by Fmoc solid-phase peptide synthesis (SPPS) on 2-chlorotritylchloride resin, using HATU as the coupling reagent. The final peptides were cleaved from the resin using a mild cleavage cocktail (trifluoroethanol-acetic acid-dichloromethane, 1:1:8) to leave the side chain tert-butyl protecting group in place for the cyclization (Scheme S2B). The crude side chain protected linear peptides were cyclized head-to-tail and coupled to the 
thalidomide building block as above. Removal of the tert-butyl side chain protecting group, however, required forcing conditions (62\% trifluoroacetic acid for $24 \mathrm{~h}$ ), resulting in highly complex product mixtures, which complicated purification by preparative HPLC. Milder deprotection conditions resulted in incomplete or no conversion as determined by LC/MS (data not shown). Nonetheless, hydroxamate-containing candidates $\mathbf{3}$ and $\mathbf{4}$ (Figure 2) were obtained in sufficient amounts and purities for biological evaluation.
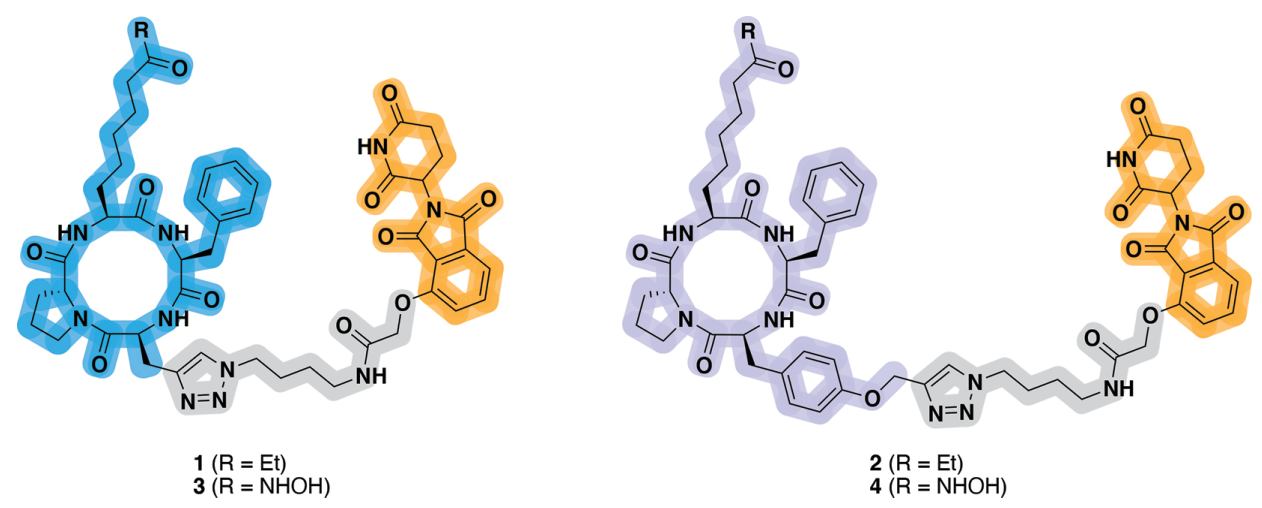

Figure 2. Chemical structures of the final PROTAC candidates 1-4. The two different HDAC inhibitor parts shown in blue and purple, respectively. The common linker and thalidomide segments are shown in gray and orange. Please consult Supporting Schemes S1-3 for synthetic details.

HDAC Inhibition In Vitro. To ensure that the final candidates targeted class I HDACs, we subjected the compounds to biochemical characterization using recombinant enzymes in vitro. We performed standard trypsin-coupled HDAC inhibition assays using a fluorogenic substrate ${ }^{7}$ with all class I HDACs to confirm enzyme inhibition and thereby target binding. Representative HDACs of class IIa, IIb, and IV were selected to evaluate class selectivity.

We could confirm selectivity and high to medium potency of all four compounds for class I HDACs. For the ethyl ketones 1 and 2, we obtained $\mathrm{IC}_{50}$ values between $50 \mathrm{nM}$ and $1000 \mathrm{nM}$ (Table 1 and Figure S1). Thus, the compounds were less potent than the parent HDAC inhibitor 
TpxB Aoda , which is characterized by $\mathrm{IC}_{50}$ values in the low nanomolar range. ${ }^{20} \mathrm{We}$ assume that this loss in potency is caused by steric effects in the active site due to the attached linker and thalidomide molecule. Low-nanomolar $\mathrm{IC}_{50}$ values of the hydroxamates $\mathbf{3 , 4}$ (Table 1 and Figure S1) showed more potent class I HDAC inhibition compared to the ethyl ketones $\mathbf{1 , 2}$ and similar potency compared to the parent inhibitor TpxB ${ }^{\text {Asuha }} \cdot{ }^{20}$ However, high selectivity for class I HDACs 1-3 was demonstrated for the ethyl ketone compounds in particular. Not surprisingly, the higher potency of the hydroxamate-containing compounds also went hand in hand with decreased selectivity over other HDACs (Table 1 and Figure S1).

Generally, we observed a higher potency for compounds $\mathbf{2}$ and $\mathbf{4}$, containing the longer tyrosinebased spacer. Presumably, the phenyl ring of the tyrosine spacer is accommodated more similarly to the Phe residue of trapoxin B than the triazole group in the compounds with the shorter linker.

Table 1. $\mathrm{IC}_{50}$ values \pm standard deviation in $\mathrm{nM}$ for the inhibition of HDACs by compounds $\mathbf{1}-\mathbf{4}$ and their parent macrocyclic inhibitors $\mathrm{TpxB}^{\mathrm{Aoda}}$ and $\mathrm{TpxB}^{\mathrm{Asuha}}$.

\begin{tabular}{ccccccc}
\hline & $\mathbf{1}$ & $\mathbf{2}$ & $\mathbf{3}$ & $\mathbf{4}$ & $\mathbf{T p x B}^{\text {Aoda }}$ & $\mathbf{T p x}^{\text {Asuha }}$ \\
\hline HDAC1 & $931 \pm 6.3$ & $77.1 \pm 0.4$ & $4.01 \pm 0.01$ & $1.02 \pm 0.01$ & $7.11 \pm 0.4$ & $2.08 \pm 0.8^{a}$ \\
HDAC2 & $1250 \pm 56$ & $92.3 \pm 0.7$ & $4.43 \pm 0.01$ & $1.27 \pm 0.01$ & $5.90 \pm 1.1^{a}$ & $1.80 \pm 0.01^{a}$ \\
HDAC3 & $498 \pm 2.5$ & $4.43 \pm 0.01$ & $9.96 \pm 0.01$ & $1.79 \pm 0.04$ & $1.58 \pm 0.3^{a}$ & $2.64 \pm 0.2^{a}$ \\
HDAC4 & NA $^{b}$ & NA $^{b}$ & $31000 \pm 198$ & $728 \pm 1.6$ & & \\
HDAC6 & NA $^{b}$ & $37300 \pm 263$ & $240 \pm 9.2$ & $30 \pm 3.6$ & & \\
HDAC7 & NA $^{b}$ & NA $^{b}$ & $20500 \pm 302$ & $770 \pm 38$ & & \\
HDAC8 & $7600 \pm 141$ & $38500 \pm 421$ & $99.4 \pm 0.6$ & $1.8 \pm 0.2$ & & \\
HDAC11 & NA $^{b}$ & $69000 \pm 1531$ & $26000 \pm 1226$ & $1300 \pm 53$ & &
\end{tabular}

${ }^{a} \mathrm{IC}_{50}$ values are calculated from $K_{\mathrm{i}}$ values previously reported. ${ }^{20 b} \mathrm{NA}=$ not active (characterized by less than $15 \%$ inhibition at highest tested concentration of $50 \mu \mathrm{M}$ ). All values are based on at least two individual assays performed in duplicate.

Inhibition Kinetics of Compounds towards Class I HDACs. Because the inhibition kinetics may affect the formation of the ternary complex necessary for the targeted protein degradation, we 
investigated the kinetics of the inhibition of class I HDACs (HDAC1-3). Rate inhibition assays revealed a fast-on/fast-off binding mechanism for the ethyl ketones $\mathbf{1}$ and $\mathbf{2}$, demonstrated by constant velocity rates (fluorophore release as a function of time; Figures S2-S7). These results prompted us to first uncover the mechanism of inhibition of the compounds $\mathbf{1}$ and $\mathbf{2}$. The data obtained from rate inhibition assays were fitted to the Michaelis-Menten equation to provide $v_{\max }$ and $K_{\mathrm{M}}$ values as well as the dissociation constants for competitive $\left(K_{\mathrm{is}}\right)$ and uncompetitive $\left(K_{\mathrm{ii}}\right)$ inhibition (Figure 3 and Table 2). Furthermore, the Michaelis-Menten parameters were fitted in secondary plots to allow visual determination of the mechanism of inhibition (Figures S2-S7). The secondary plots revealed mixed inhibition, categorizing the inhibitors as non-competitive. However, the associated $K_{\mathrm{i}}$ values indicate primarily competitive inhibition, because the $K_{\text {is }}$ values (competitive inhibition) were significantly lower than the $K_{\text {ii }}$ values (uncompetitive inhibition; see Figure 3 for example showing compound $\mathbf{1}$ ).

In contrast, the velocity changed over time in the rate inhibition assay of the hydroxamates $\mathbf{3}$ and 4, which indicated a slow, tight-binding mechanism of these compounds (Figure S8). For compounds 3 and $\mathbf{4}$, we performed dose-response assays to distinguish between mechanism A and $\mathrm{B}$ of slow-binding inhibition. To this end, the apparent first-order rate constant $k_{\mathrm{obs}}$, describing the change in velocity over time, was calculated, plotted as a function of time, and fitted to equations for mechanism A and B (see the Supporting Information for additional information). ${ }^{65} \mathrm{We}$ determined inhibition according to mechanism B for both compounds and estimated the mechanism B-based dissociation constants $K_{\mathrm{i}}$ (Table 2 and Figure S8). As most of the values approach zero, $K_{\mathrm{i}}$ values could not be calculated in all cases, but were as a minimum smaller than the lowest concentration used to perform the assay. 

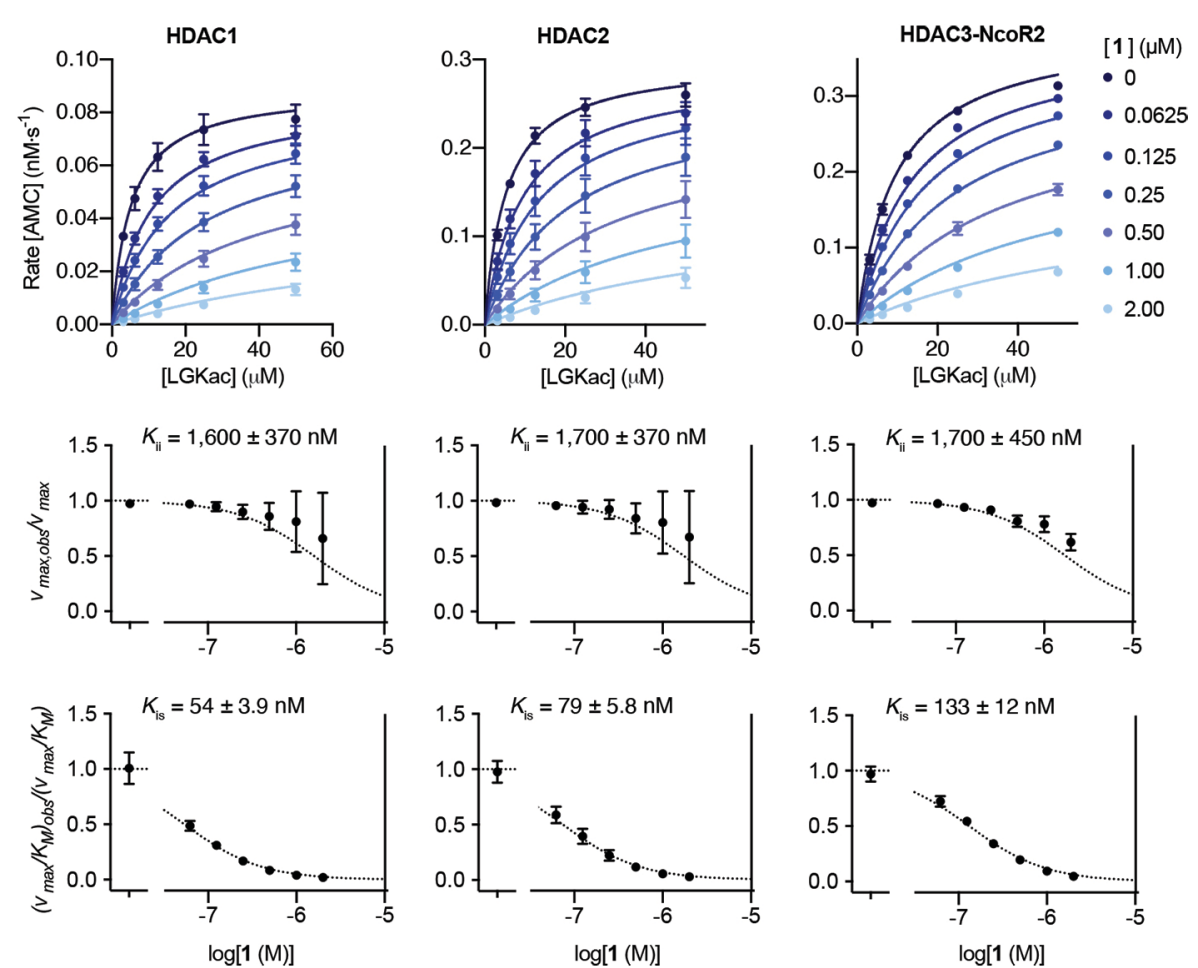

Figure 3. Kinetic evaluation of fast-on/fast-off binding compound 1. Michaelis-Menten plots and data fitting for inhibition of HDAC1-3 by compound 1.

Table 2. Binding kinetics of fast-on/fast-off ethyl ketone-based compounds $\mathbf{1 , 2}$ and tight binding hydroxamate-based compounds $\mathbf{3 , 4}$ investigated against HDAC1-3. ${ }^{a}$

\begin{tabular}{ccccccc}
\hline & \multicolumn{2}{c}{$\mathbf{1}$} & \multicolumn{2}{c}{$\mathbf{2}$} & $\mathbf{3}$ & $\mathbf{4}$ \\
\cline { 2 - 7 } & $K_{\text {is }}$ & $K_{\text {ii }}$ & $K_{\text {is }}$ & $K_{\text {ii }}$ & estimated $K_{\mathrm{i}}{ }^{b}$ & estimated $K_{\mathrm{i}}{ }^{b}$ \\
\hline HDAC1 & $54 \pm 3.9$ & $1600 \pm 370$ & $34 \pm 3.3$ & $1000 \pm 770$ & $<<0.98$ & $\sim 0.02$ \\
HDAC2 & $79 \pm 5.8$ & $1700 \pm 370$ & $16 \pm 3.2$ & $75 \pm 19$ & $<<0.98$ & $<<0.98$ \\
HDAC3 & $133 \pm 12$ & $1700 \pm 450$ & $22 \pm 8.8$ & $130 \pm 55$ & $<<0.98$ & $\sim 0.10$
\end{tabular}

${ }^{a} K_{\text {is }}$ and $K_{\text {ii }}$ values are reported in nM. ${ }^{b} K_{\mathrm{i}}$ values could not be calculated as they depend on $k-2$ values, which approached 0 with uncertainties exceeding the determined values. Therefore, estimated maximum values are given in $\mathrm{nM}$.

Evaluation of Cytotoxic Effects. In order to evaluate the suitability of our compounds for protein degradation studies in cells, we examined their effect on cell viability as judged by MTT assays. To this end, human embryonic kidney cells (HEK293T) were treated with the compounds for $72 \mathrm{~h}$. All compounds $\mathbf{1}-\mathbf{4}$ exhibited only limited to no cellular toxicity, up to the highest tested concentration of $100 \mu \mathrm{M}$ (Figure S9). This is in contrast to other potent HDAC inhibitors like the 
natural compound trichostatin A (TSA), used as control in the assay, and to the parental macrocyclic inhibitors, which the degraders are based on $\left(6.2 \mu \mathrm{M}\right.$ for $\mathrm{TpxB}^{\mathrm{Aoda}}$ and $0.3 \mu \mathrm{M}$ for TpxB Asuha , respectively). ${ }^{20}$ This might reflect limited cell permeability or enhanced efflux of the bifunctional molecules, but also their fundamentally different mode of action. Nevertheless, we welcomed the lack of general cytotoxicity of these compounds, because it enables cellular protein degradation studies without interference from apoptosis or other cell death mechanisms.

Characterization of HDAC Degradation. To test the ability of our compounds to induce HDAC protein degradation, we incubated HEK293T cells with the compounds, lysed the cells, prepared nuclear extracts, and assessed protein content by Western blot analyses. We initially picked HDAC2 as a representative for class I HDACs, because the commercial primary antibody performed very well in our immunoblots. Loading was controlled by the level of total histone H3 in the nuclear extracts. Decrease in HDAC2 levels was only observed for the compounds with the longer tyrosine-based linker 2 and 4 (Figure 4A). Protein degradation was more pronounced for the ethyl ketone-bearing compound $\mathbf{2}$ than for hydroxamate $\mathbf{4}$, even though compound $\mathbf{4}$ is a more potent HDAC inhibitor (Table 1). This may be rationalized by the observed binding kinetics (vide supra) combined with the principle of how PROTACs exert their catalytic effect. The slow offrate and effectively irreversible binding of hydroxamate 4 leads to potent inhibition but is not compatible with fast catalytic turnover in the ubiquitination that leads to HDAC degradation. Slow, tight-binding kinetics can be beneficial for occupancy-driven pharmacology (classical enzyme inhibitors), ${ }^{66-67}$ but might be unfavorable for event-driven pharmacology (PROTACs).

Based on the initial screen, we focused our attention on the ethyl ketone 2, which appeared to be the most potent HDAC degrader. When treating HEK293T cells with 2 (300 nM) in varying time 
intervals, it was found that efficient degradation was achieved after as little as two to four hours (Figure 4B-C). On the other hand, longer exposure (eight hours or more) resulted in HDAC2 levels similar to or stronger than the negative control. While the reason for this is not clear based on our current level of insight, it points to activation of protein re-expression upon induced degradation. Therefore, cells were co-treated with an inhibitor of ribosomal protein biosynthesis, cycloheximide (CHX), ${ }^{53,68}$ as performed previously in the investigation of PROTACs. ${ }^{53,69-71}$ A similar trend was observed for the closely related enzyme HDAC1 (Figure 4B) and co-treatment with cycloheximide led to Western blots showing markedly enhanced degradation (Figure 4D).

A

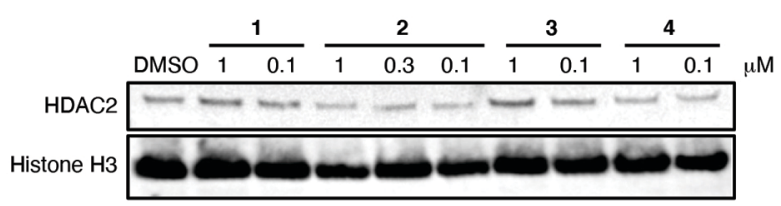

B

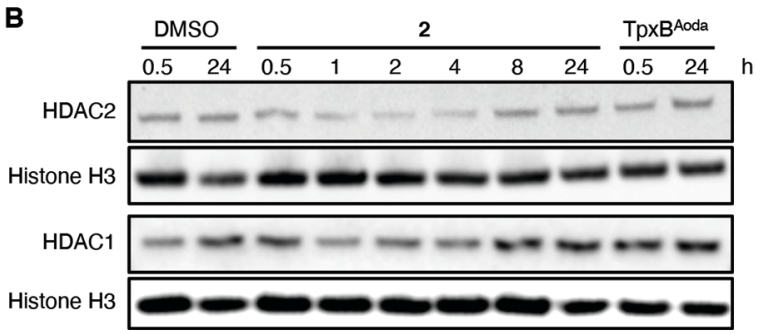

C

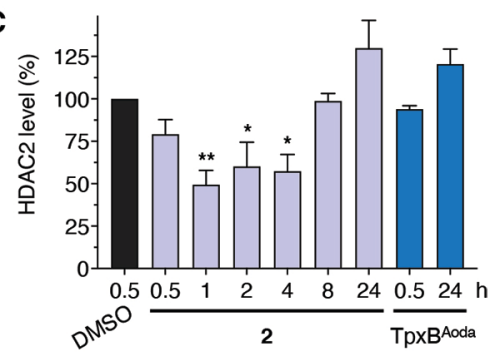

D

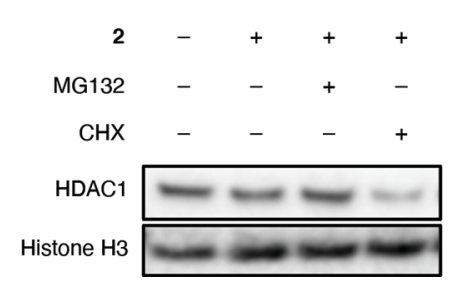

Figure 4. Characterization of protein degradation capabilities of compounds 1-4. (A) Screening of the series of test compounds for degradation of HDAC2 upon treatment of HEK293T cells for 4 hours at the indicated concentrations and co-treatment with cycloheximide (CHX). (B) Time course of degradation of HDAC2 and HDAC1 upon treatment of HEK293T cells with $0.3 \mu \mathrm{M} 2$ or $0.3 \mu \mathrm{M}$ reference inhibitor $\mathrm{TpxB}^{\mathrm{Aoda}}$ for the indicated times. (C) Quantification of HDAC2 levels after treatment of HEK293T cells with $300 \mathrm{nM} 2$ or reference inhibitor TpxB ${ }^{\text {Aoda }}$ for different times. ${ }^{*}-p<0.05,{ }^{* *}-p<0.01(n=3)$ using $t$-test. (D) Mechanistic studies reveal proteasome-dependent HDAC1 degradation by $\mathbf{2}$ as co-treatment with proteasome inhibitor MG132 does not lead to degradation and reveal enhanced degradation by co-treatment with cycloheximide (CHX); representative blot from two replicates. For full blot images, please consult the Supporting Information. 
Importantly, treatment with the parent HDAC inhibitor $\left(\mathrm{TpxB}^{\mathrm{Aoda}}\right)$ did not lead to degradation of HDAC1 or HDAC2 (Figure 4B). The observation that compound 2 leads to short term intervention and temporal degradation of HDACs may also provide an explanation for the lack of general cytotoxicity measured by MTT assay after $72 \mathrm{~h}$ treatment.

The degradation of HDACs could be counteracted by co-treatment of cells with the proteasome inhibitor MG132 72 (Figure 4D) or by co-treatment with a competing HDAC inhibitor (Figure 5C), which highlights the requirement for both binding to the enzyme and a functional ubiquitinproteasome pathway for efficient degradation.

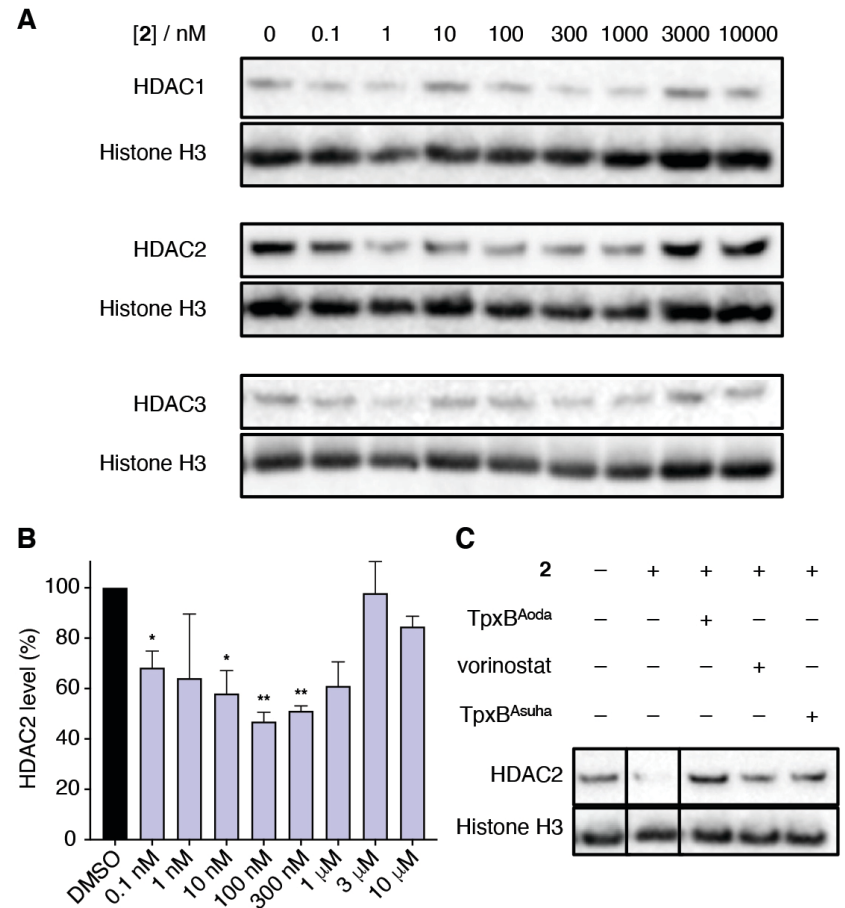

Figure 5. Characterization of protein degradation capabilities of compound 2. (A) Titration series testing for degradation of HDAC1-3 upon treatment of HEK293T cells with 2 for 4 hours at the indicated concentrations. (B) Quantification of HDAC2 levels after treatment of HEK293T cells with different concentrations of 2 for 4 hours to determine optimal conditions. ${ }^{*}-p<0.05,{ }^{*}-p<0.01(n=2)$ using $t$ test. (C) Degradation of HDAC2 by 2 can be overcome by co-treatment with HDAC inhibitors competing for the same binding site (used at $1 \mu \mathrm{M}$ ); representative blot from two replicates. For full blot images, please consult the Supporting Information. 
In a dose-response experiment, we observed optimal degradation of HDACs1-3 after treatment with concentrations of 2 at $100-300 \mathrm{nM}$ for 4 hours (Figure 5A,B). Notably, at elevated concentrations (equal to or above $1 \mu \mathrm{M}$ ), degradation was less efficient than at lower

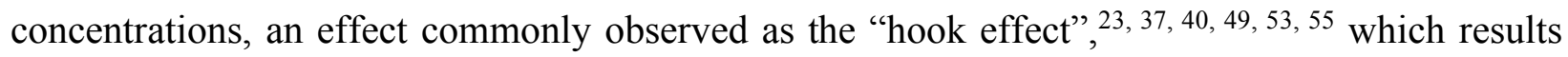
from incomplete formation of the ternary ligase:PROTAC:POI (protein of interest) complex at high concentrations, when formation of two separate binary complexes (ligase:PROTAC and PROTAC:POI) becomes more likely due to saturation of the targets.

\section{Degradation of Proteins Associated with Class I HDACs and Effect on Histone Acetylation.}

Next, we extended our analyses to other proteins that might be affected by degradation induced by compound 2, because of their known association with class I HDACs in the nucleus. ${ }^{9-10}$ Based on antibody availability, we focused our analyses on REST corepressor 1 (CoREST), metastasisassociated protein 3 (MTA3), lysine-specific demethylase 1 (LSD1), and TBL1XR1. Of these, a significant reduction in protein level was only observed for TBL1XR1 (by ca. 40\%, Figure 6A,B). Degradation of proteins, which themselves do not bind to the PROTAC molecule, but are associated with and thus in proximity to another protein that does, has been termed "collateral" or "bystander" ubiquitination. This effect has recently also been observed for degradation of proteins in the polycomb repressive complex 2 (PRC2). ${ }^{36,50}$

To investigate downstream effects of HDAC degradation, we determined histone acetylation levels in HEK293T cells after 4 hours of treatment. For the H3K9ac and H3K27ac marks, increased acetylation levels upon treatment with $\mathbf{2}$ were observed, comparable to levels upon treatment with parent inhibitor $\mathrm{TpxB}^{\text {Aoda }}$ (Figure 6C). Importantly, cells that were also co-treated 
with proteasome inhibitor MG132 did not show the same increase, indicating that the elevated acetylation levels upon treatment with $2(300 \mathrm{nM})$ stem from its function as an HDAC degrader.

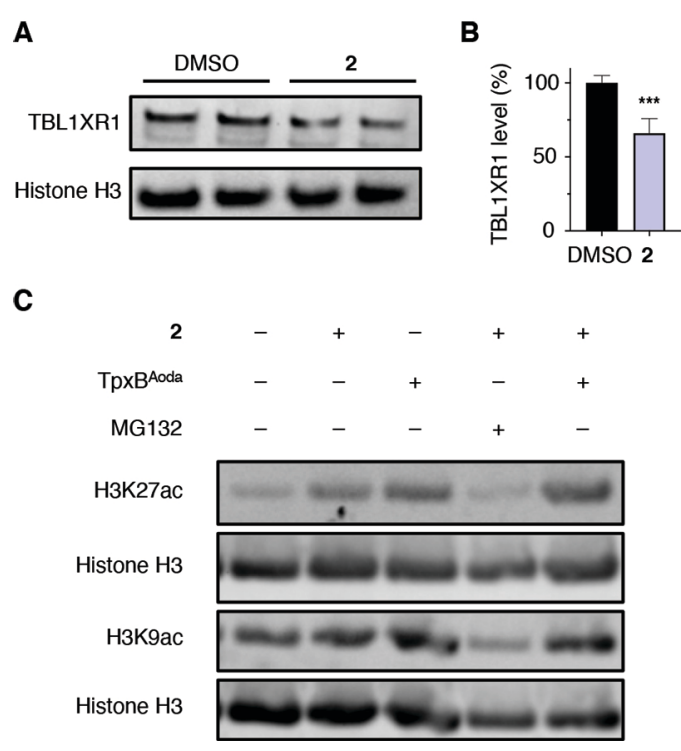

Figure 6. Characterization of further effects caused by compound 2 induced protein degradation. (A) The protein TBL1XR1, one of the proteins in the NCoR complex associated with class I HDACs, is also degraded after $4 \mathrm{~h}$ treatment with $300 \mathrm{nM}$ 2. (B) Quantification of TBL1XR1 levels after $4 \mathrm{~h}$ treatment with $300 \mathrm{nM} 2$. $* * *-p<0.001(n=4)$ using $t$-test. (C) Effects of HDAC degradation by $300 \mathrm{nM} 2$ or by treatment with $300 \mathrm{nM} \mathrm{TpxB}^{\text {Aoda }}$ on acetylation of histone lysine marks H3K27ac and H3K9ac after 4 hours; representative blot from two replicates. For full blot images, please consult the Supporting Information.

Lastly, we investigated whether compound $\mathbf{2}$ exhibited selective degradation of certain histone deacetylases. To this end, HEK293T cells were treated with $2(300 \mathrm{nM})$ for 4 hours and nuclear extracts as well as cytosolic fractions were isolated. The levels of the respective HDAC proteins in both fractions were then analyzed by Western blotting. For the cytosolic fractions, we used the constitutively expressed metabolic enzyme glyceraldehyde 3-phosphate dehydrogenase (GAPDH) as loading control. Significant degradation was not observed for any of the other tested HDAC proteins (HDAC4-9 and 11, Figure S10). Importantly, we observed no degradation of HDAC6, the main target of all previously reported HDAC degraders. ${ }^{54-58}$ 
To the best of our knowledge, compound $\mathbf{2}$ is the first example, where such a high selectivity for class I HDACs without degrading other HDAC enzymes has been demonstrated. However, during the preparation of this manuscript, Smalley et al. also reported compounds capable of degrading class I HDACs. ${ }^{59}$ Their chemotypes were based on a different HDAC-targeting scaffold (o-aminobenzamide as zinc-binding group) and a different ligase-recruiting element for the most potent example. Notable differences in the cellular effects of those compounds were reported. They exhibited HDAC degradation after $24 \mathrm{~h}$ treatment, a time point where our compounds no longer show efficacy. Presumably, due to this prolonged effect, the compounds in that study also exhibited toxicity towards cultured HCT116 cells (colon cancer). Moreover, while efficient degradation was demonstrated for HDAC1-3, the potential effect on other HDACs or protein complex partners was not reported and selectivity was therefore not addressed. ${ }^{59}$

The degraders presented in the present study therefore provide a valuable complementary strategy, which allows for probing the biological effects of short term deletion of class I HDACs and, potentially, associated complex partners without exhibiting detrimental general cytotoxicity.

\section{DISCUSSION}

Here, we report the development of a selective and non-toxic protein degrader of class I HDACs. Based on highly potent and class I-selective macrocyclic tetrapeptide inhibitors, we employed a modular click chemistry approach to synthesize a small series of candidates, of which the most efficient compound (2) is capable of chemically inducing degradation of class I histone deacetylases (HDAC1-3). Degradation by compound $\mathbf{2}$ is dependent on active site binding as well as on a functional proteasome and is dose- and time-dependent, with optimal degradation at submicromolar concentrations after 4 hours. While degradation of HDAC1-3 leads to concomitant 
histone hyperacetylation and partial degradation of one protein complex partner, it does not lead to general cytotoxicity as sustained treatments with traditional HDAC inhibitors do. Since the PROTAC concept has several advantages over genetic protein knockdown approaches and occupancy-driven inhibitors, we expect this probe to enable novel types of investigations of the biological effects of short-term perturbation of these enzymes.

Finally, compound $\mathbf{2}$ is the first example of a protein degrader employing a macrocyclic peptide as its target-recruiting motif. Cyclic peptides have been recognized as a privileged structure for chemical tools, recognizing protein surfaces and for studying protein-protein interactions ${ }^{73}$ and efficient methods exist for generating large libraries and identifying potent binders, e. g. by phagedisplay. ${ }^{74-76}$ or mRNA-display. ${ }^{77-80}$ We provide here a first proof-of-concept that cyclic peptides can be elaborated into cell-permeable protein degraders, which opens up new avenues for the field of PROTAC design against "difficult to target" proteins of interest.

\section{MATERIALS AND METHODS}

Synthesis. All compounds were synthesized in-house (see Supporting Information) and were of at least $95 \%$ purity for in vitro and in cellulo testing. All compounds 1-4 were tested for known classes of assay interference compounds using the publicly available online tool "False Positive Remover" (www.cbligand.org/PAINS). None of the tested compounds were flagged as PAINS. Reference HDAC inhibitors $\mathrm{TpxB}^{\mathrm{Aoda}}$ and $\mathrm{TpxB}^{\mathrm{Asuha}}$ were available from an earlier investigation. ${ }^{20}$ Concentrations of test compound stock solutions were determined by quantitative ${ }^{1} \mathrm{H}-\mathrm{NMR}$ using maleic acid as internal standard. Reagents for cell co-treatment such as cycloheximide (CHX) and MG132 were purchased from Sigma-Aldrich. 
Trypsin-Based Fluorogenic Enzyme Activity Assays. All assays were performed in black half-area 96-well plates (Corning) with duplicate series and at least two repetitions of each assay. HDAC buffer (50 mM Tris, $137 \mathrm{mM} \mathrm{NaCl}, 2.7 \mathrm{mM} \mathrm{KCl}, 1 \mathrm{mM} \mathrm{MgCl} 2,0.5 \mathrm{mg} / \mathrm{mL}$ BSA) was used for all reactions except for HDAC11 where HEPES buffer (50 mM HEPES/Na, $100 \mathrm{mM} \mathrm{KCl,}$ 2.7 mM KCl, $1 \mathrm{mM} \mathrm{MgCl} 2,0.5 \mathrm{mg} / \mathrm{mL}$ BSA) was used instead. Different substrates were selected depending on the enzyme: Ac-LGK(ac)-AMC was used as substrate for HDAC1, 2, 3, and 6, AcLGK(tfa)-AMC for HDAC4, 7, and 8, and Ac-ETDK(myr)-AMC for assays performed with HDAC11. All assays were performed under steady-state conditions ensured by $5 \%$ to $20 \%$ of substrate conversion. All assays were analyzed using the plate reader FLUOstar Omega (BMG Labtech) at $\lambda_{\mathrm{ex}}=360 \mathrm{~nm}$ and $\lambda_{\mathrm{em}}=460 \mathrm{~nm}$ at room temperature. The AMC concentration was calculated based on a fluorescence standard curve and all data were analyzed by nonlinear regression using GraphPad Prism.

Endpoint HDAC Inhibition Assays. Substrate and different inhibitor concentrations (3-fold dilutions) were added to the wells and the reaction was started by adding a freshly prepared HDAC solution. (HDAC1: $0.2 \mathrm{ng} / \mu \mathrm{L}, \mathrm{HDAC} 2: 0.1 \mathrm{ng} / \mu \mathrm{L}, \mathrm{HDAC} 3: 0.11 \mathrm{ng} / \mu \mathrm{L}, \mathrm{HDAC} 4: 4.0 \mathrm{pg} / \mu \mathrm{L}$, HDAC6: $0.3 \mathrm{ng} / \mu \mathrm{L}, \mathrm{HDAC7}: 5.5 \mathrm{pg} / \mu \mathrm{L}, \mathrm{HDAC} 8: 0.05 \mathrm{ng} / \mu \mathrm{L}, \mathrm{HDAC} 11: 0.05 \mathrm{nM}$; all enzymes were purchased from BPS Bioscience). The plate was incubated for $30 \mathrm{~min}$ at $37{ }^{\circ} \mathrm{C}$. After the addition of a freshly prepared solution of $0.4 \mathrm{mg} / \mathrm{mL}$ trypsin, the assay was developed for $15 \mathrm{~min}$ at $37{ }^{\circ} \mathrm{C}$ and then measured in the plate reader. Each plate contained wells without inhibitor (positive control, 100\% conversion) and control wells without enzyme and inhibitor (negative control, blank). Apicidin, a potent class I HDAC inhibitor, was used as control for assays with HDAC1, 2 and 3. The pan-HDAC inhibitor Trichostatin A (TSA) served as control for all assays performed with HDAC4, 6, 7, 8, and 11. 
Rate Inhibition Assay with one Inhibitor. Rate inhibition assays were performed for HDAC1, 2 and 3 and analyzed as previously described. ${ }^{20}$ Different substrate concentrations (2-fold dilutions), different inhibitor concentrations (2-fold dilutions) and trypsin $(10 \mathrm{ng} / \mu \mathrm{L})$ were added to the wells and the reaction was started by adding a freshly prepared HDAC solution. Fluorescence was recorded every $30 \mathrm{sec}$ for 60 minutes. Resulting data was analyzed using GraphPad Prism.

Dose-response assay. Rate inhibition assays were performed for HDAC1, 2, and 3 and analyzed as previously decribed. ${ }^{20}$ Substrate, different inhibitor concentrations (2-fold dilutions) and trypsin $(10 \mathrm{ng} / \mu \mathrm{L})$ were added to the wells and the reaction was started by adding a freshly prepared HDAC solution. Fluorescence was recorded every $30 \mathrm{sec}$ for 60 minutes. The resulting data were analyzed using GraphPad Prism.

Cell viability assay. An MTT assay was performed to assess effects on cell viability using an MTT assay kit from Merck Millipore (CT02). At 70-80\% confluency, cells were seeded into sterile 96-well plates. After incubation at $37{ }^{\circ} \mathrm{C}$ and $5 \% \mathrm{CO}_{2}$ atmosphere overnight, cells were treated with $10 \mu \mathrm{L}$ of medium containing dilution series of test compounds and incubated at $37^{\circ} \mathrm{C}$ and $5 \% \mathrm{CO}_{2}$ atmosphere for $72 \mathrm{~h}$. Trichostatin A (TSA) was used as positive and DMSO as negative control. After $72 \mathrm{~h}, 10 \mu \mathrm{L}$ of freshly prepared 3-(4,5-dimethylthiazol-2-yl)-2,5-diphenyltetrazolium bromide (MTT) solution were added to the wells and the plates incubated for another $4 \mathrm{~h}$ at $37{ }^{\circ} \mathrm{C}$ and $5 \% \mathrm{CO}_{2}$ atmosphere. $0.04 \mathrm{M}$ Hydrochloric acid was added to the wells and absorbance was measured at $560 \mathrm{~nm}$ with background subtraction at $630 \mathrm{~nm}$ using the FLUOstar Omega plate reader (BMG Labtech). Assays were performed in triplicate and data were analyzed using GraphPad Prism.

Cellular Protein Degradation. Cell culture. Human embryonic kidney HEK293T cells (ATCC) were cultured in T175 flasks in Dulbecco's modified eagle medium (DMEM, ThermoFisher), 
supplemented with $10 \%$ fetal bovine serum (FBS) and $1 \%$ penicillin/streptomycin at $37{ }^{\circ} \mathrm{C}$ and $5 \% \mathrm{CO}_{2}$ atmosphere. Cells were grown to $70-80 \%$ confluency as determined visually by a light microscope, washed once with phosphate buffered saline (PBS) to remove dead and floating cells. Cells were treated with $2 \mathrm{~mL}$ trypsin-EDTA solution (Sigma-Aldrich) at $37{ }^{\circ} \mathrm{C}$ for some minutes. After complete detachment, the cell suspension was diluted with medium and cells were counted using trypan blue stain on an Eve automated cell counter (NanoEnTek). Before treatment, cells were seeded at 1,000,000 cells per well in $2 \mathrm{~mL}$ medium on sterile 6-well plates and grown at $37^{\circ} \mathrm{C}$ and $5 \% \mathrm{CO}_{2}$ atmosphere overnight.

Cell treatment. Compounds and co-treatment reagents were dissolved in cell culture medium as 11 -fold stocks and $200 \mu \mathrm{L}$ per well were added to the cells. Unless otherwise noted, cells were treated for 4 hours at $37{ }^{\circ} \mathrm{C}$ and $5 \% \mathrm{CO}_{2}$ atmosphere. In case of co-treatment, $100 \mu \mathrm{g} / \mathrm{mL} \mathrm{CHX}$ or $10 \mu \mathrm{M}$ MG132 (final concentrations) were added. Cells were harvested by scraping and transferred into $15 \mathrm{~mL}$ falcon tubes. After centrifugation at $1.5 \mathrm{rpm}$ for $2.5 \mathrm{~min}$ at $\mathrm{rt}$, medium was removed by suction and the cell pellet was washed twice with PBS before nuclear extract preparation. All treatments and following analyses were performed at least in duplicate.

Nuclear extract preparation. Cell pellets were resuspended in $250 \mu \mathrm{L}$ hypotonic buffer $(20 \mathrm{mM}$ Tris, $10 \mathrm{mM} \mathrm{NaCl}, 3 \mathrm{mM} \mathrm{MgCl}$, $\mathrm{pH}$ 7.4). The suspensions were transferred into $1.5 \mathrm{~mL}$ Eppendorf tubes and incubated on ice for 15 min to lyse the cells. $10 \mu \mathrm{L}$ of $10 \% \mathrm{NP}-40$ surfactant solution (ThermoFisher, Surfactant Amps) were added and the lysates were vortexed at the highest setting for $10 \mathrm{sec}$. After centrifugation at $4{ }^{\circ} \mathrm{C}$ and $500 \mathrm{rcf}$ for $10 \mathrm{~min}$ (Eppendorf Centrifuge 5417R), the supernatant was collected as the cytosolic fraction. The pellet was washed twice with $125 \mu \mathrm{L}$ ice-cold PBS followed by centrifugation at $4{ }^{\circ} \mathrm{C}$ and $500 \mathrm{rcf}$ for $10 \mathrm{~min}$. After the last washing step, the nuclear pellet was resuspended in $55 \mu \mathrm{L}$ cell extraction buffer (ThermoFisher) 
supplemented with $1 \mathrm{mM}$ phenylmethylsulfonyl fluoride (PMSF, Sigma-Aldrich) and $10 \mu \mathrm{L}$ protease inhibitor solution (Roche, Complete EDTA-free) and stored on ice for 45 min, while vortexing at the highest setting for several seconds every $15 \mathrm{~min}$. The samples were sonicated on ice for $1 \mathrm{~min}$ with a pulsed program ( $2 \mathrm{sec}$ sonication pulse, $2 \mathrm{sec}$ pause, total ca. $1.5 \mathrm{~kJ} / \mathrm{sample}$ ) and finally centrifuged at $4{ }^{\circ} \mathrm{C}$ and $14,000 \mathrm{rcf}$ for $30 \mathrm{~min}$. The supernatant (nuclear extract) was transferred to a fresh Eppendorf tube, frozen, and stored at $-80{ }^{\circ} \mathrm{C}$.

Determination of protein concentration. The total protein concentration of the nuclear extracts was determined by BCA assay. To this end, $2 \mu \mathrm{L}$ extract sample was diluted with $18 \mu \mathrm{L}$ water and reacted with $160 \mu \mathrm{L}$ freshly prepared BCA reagent solution containing bicinchoninic acid and $\mathrm{CuSO}_{4}$ on transparent 96 -well plates at $37{ }^{\circ} \mathrm{C}$ for approx. 30 min under shaking. After complete color development, absorbance was measured on a FLUOStar Omega plate reader at $\lambda=562 \mathrm{~nm}$ and compared to a standard curve of absorbance values obtained for samples containing $0.016-$ $1.000 \mathrm{mg} / \mathrm{mL}$ BSA (Protein Micro Standard, Sigma-Aldrich) on the same plate.

Protein separation by sodium dodecylsulfate polyacrylamide gel electrophoresis (SDS-PAGE). SDS-PAGE was performed on an XCell SureLock mini-cell electrophoresis system (ThermoFisher). Samples were prepared from an appropriate volume of nuclear extract to contain $7 \mu \mathrm{g}$ total protein, diluted with MilliQ water to $13 \mu \mathrm{L}$ and supplemented with $5 \mu \mathrm{L} 4$ X NuPAGE LDS sample buffer (ThermoFisher) and $2 \mu \mathrm{L} \mathrm{10X} \mathrm{NuPAGE} \mathrm{sample} \mathrm{reducing} \mathrm{agent} \mathrm{(ThermoFisher).} \mathrm{Samples}$ were heated to $85^{\circ} \mathrm{C}$ for $10 \mathrm{~min}$, cooled on ice, and spun down. $18 \mu \mathrm{L}$ of this sample were loaded on ready-made NuPAGE 4-12\% Bis-Tris gels (ThermoFisher) together with Precision Plus Protein WesternC Standard (Bio-Rad) as ladder in one lane. Gels were typically run for 40 min at $200 \mathrm{~V}$ in NuPAGE MES SDS running buffer (ThermoFisher). 
Western Blotting using HRP detection. The XCell SureLock MiniCell electrophoresis system (ThermoFisher) was used to transfer proteins from the gels onto polyvinylidene difluoride (PVDF) membranes. Membranes were cut to size and activated by soaking in methanol for $30 \mathrm{sec}$, followed by 2 min in water, and several minutes in NuPAGE transfer buffer (ThermoFisher). Sponges, filter paper, and the gel were also soaked in transfer buffer and assembled according to the manufacturer's instructions together with the activated membrane. Transfers were performed at $30 \mathrm{~V}$ for 1 hour at room temperature. After completion, the membrane was rinsed in TBST, cut, and blocked in 5\% skim milk powder (w/v, Sigma-Aldrich) in TBST for 1 hour under constant rocking. After blocking, the membrane was washed with TBST for $3 \times 5$ min and subsequently incubated with primary antibody (typically $1: 1,000)$ in $2 \%$ skim milk (w/v) at $4{ }^{\circ} \mathrm{C}$ overnight. The next day, the membrane was washed with TBST for $3 \times 5 \mathrm{~min}$ and subsequently incubated with secondary antibody (typically 1:10,000) and Precision Protein StrepTactin-HRP conjugate (BioRad, typically 1:20,000) in 2\% skim milk (w/v) at room temperature for 1 hour. The membrane was washed with TBST for $2 \times 5$ min and once with TBS. Blots were developed using ECL Western Blotting Substrate set (ThermoFisher) mixing the two solutions 1:1. Images were recorded on a Syngene PXi imaging station. Protein levels were quantified after western blotting using the software ImageJ (US National Institutes of Health). All degradation experiments were performed in at least two independent biological replicates (duplicates). For statistical analysis, $n$ represents the total number of quantified Western blots used for the analysis (technical replicates), while both biological replicates were used.

Western Blotting using fluorescence detection. These visualizations were performed essentially as for HRP detection, except that membranes were blocked in Licor buffer (TBS supplemented with $4.5 \mathrm{~g} / \mathrm{L}$ gelatin from cold water fish skin (Sigma-Aldrich), $1 \mathrm{~g} / \mathrm{L}$ casein (Sigma-Aldrich), and 
$0.2 \mathrm{~g} / \mathrm{L}$ sodium azide). Antibody dilutions were prepared in Licor buffer supplemented with $0.1 \%$ (v/v) Tween-20. After blocking, membranes were not washed, but treated directly with a solution of the primary antibody. Membranes were handled in black boxes or otherwise protected from light to avoid the fluorescently labeled secondary antibodies from bleaching. After incubation with the secondary antibodies (typically 1:15,000), membranes were washed with TBST for 3x5 min and dried between filter paper for at least $15 \mathrm{~min}$ before recording the images.

Antibodies. The following primary antibodies were used: HDAC1 (Santa Cruz Biotechnology, sc-7872, rabbit pAb), HDAC2 (Santa Cruz, sc-7899, rabbit pAb), HDAC3 (Santa Cruz, sc-11417, rabbit pAb and Cell Signaling Technology, CST-3949T, mouse mAb), HDAC4 (Cell Signaling, CST-7628T, rabbit mAb), HDAC5 (Santa Cruz, sc-133106, mouse mAb), HDAC6 (Santa Cruz, sc-11420, rabbit pAb), HDAC7 (Santa Cruz, sc-74563, mouse mAb), HDAC8 (Santa Cruz, sc11405, rabbit pAb), HDAC9 (Santa Cruz, sc-398003, mouse mAb), HDAC11 (RayBiotech, 10110701, mouse mAb), CoREST (Santa Cruz, sc-135873, mouse mAb), MTA3 (Santa Cruz, sc81325, mouse mAb), LSD1 (Santa Cruz, sc-27120, mouse mAb), TBL1XR1 (Santa Cruz, sc100908, mouse mAb), GAPDH (abcam, ab8245, mouse mAb), histone H3 (Cell Signaling, CST3638S, mouse mAb), H3K9ac (Merck Millipore, 07-352, rabbit pAb), H3K27ac (Cell Signaling, CST-4353S, rabbit pAb). The following secondary antibodies were used for HRP detection: antimouse-IgG HRP-conjugate (Santa Cruz, sc-2005 and Cell Signaling, CST-7076S), anti-rabbit-IgG HRP-conjugate (Santa Cruz, sc-2004 and Cell Signaling, CST-7074S). The following secondary antibodies were used for fluorescence detection: anti-mouse-IgG DyLight-800 conjugate (Cell Signaling, CST-5257S), anti-rabbit-IgG DyLight-680 conjugate (Cell Signaling, CST-5366S).

\section{ASSOCIATED CONTENT}




\section{Supporting Information.}

The following files are available free of charge.

Supporting schemes, figures, experimental procedures, compound characterization data, and copies of NMR spectra and HPLC traces (PDF)

\section{AUTHOR INFORMATION}

\section{Corresponding Author}

*cao@sund.ku.dk.

\section{ORCID}

Martin Roatsch: 0000-0002-9274-1433

Manfred Jung: 0000-0002-6361-7716

Christian A. Olsen: 0000-0002-2953-8942

\section{Conflict of interest}

The authors declare no conflict of interest.

\section{ACKNOWLEDGMENT}

M.R. acknowledges a research fellowship from the Deutsche Forschungsgemeinschaft (DFG, RO5526/1-1) and a running cost grant from Torben og Alice Frimodts Fond. A.V. and M.J. thank the DFG for funding within CRC992 (Medical Epigenetics, Project ID 192904750). C.A.O. thanks the Lundbeck foundation (R289-2018-2074t) and the Carlsberg Foundation (CF15-011) for financial support. 


\section{REFERENCES}

1. Kouzarides, T., Chromatin Modifications and Their Function. Cell 2007, 128, 693-705.

2. Arrowsmith, C. H.; Bountra, C.; Fish, P. V.; Lee, K.; Schapira, M., Epigenetic protein families: a new frontier for drug discovery. Nat. Rev. Drug Discov. 2012, 11, 384-400.

3. Schiedel, M.; Robaa, D.; Rumpf, T.; Sippl, W.; Jung, M., The Current State of NAD+Dependent Histone Deacetylases (Sirtuins) as Novel Therapeutic Targets. Med. Res. Rev. 2018, $38,147-200$.

4. Epigenetic Drug Discovery. Wiley-VCH: Weinheim, Germany, 2019.

5. Seto, E.; Yoshida, M., Erasers of Histone Acetylation: the Histone Deacetylase Enzymes. Cold Spring Harbor Perspect. Biol. 2014, 6, a018713.

6. de Ruijter, A. J. M.; van Gennip, A. H.; Caron, H. N.; Kemp, S.; van Kuilenburg, A. B. P., Histone deacetylases (HDACs): characterization of the classical HDAC family. Biochem. J. 2003, $370,737-749$.

7. Bradner, J. E.; West, N.; Grachan, M. L.; Greenberg, E. F.; Haggarty, S. J.; Warnow, T.; Mazitschek, R., Chemical phylogenetics of histone deacetylases. Nat. Chem. Biol. 2010, 6, 238243.

8. Bresciani, A.; Ontoria, J. M.; Biancofiore, I.; Cellucci, A.; Ciammaichella, A.; Di Marco, A.; Ferrigno, F.; Francone, A.; Malancona, S.; Monteagudo, E.; Nizi, E.; Pace, P.; Ponzi, S.; Rossetti, I.; Veneziano, M.; Summa, V.; Harper, S., Improved Selective Class I HDAC and Novel 
Selective HDAC3 Inhibitors: Beyond Hydroxamic Acids and Benzamides. ACS Med. Chem. Lett. 2019, $10,481-486$.

9. Haberland, M.; Montgomery, R. L.; Olson, E. N., The many roles of histone deacetylases in development and physiology: implications for disease and therapy. Nat. Rev. Gen. 2009, 10, 3242.

10. Song, Y.; Dagil, L.; Fairall, L.; Robertson, N.; Wu, M.; Ragan, T. J.; Savva, C. G.; Saleh, A.; Morone, N.; Kunze, M. B. A.; Jamieson, A. G.; Cole, P. A.; Hansen, D. F.; Schwabe, J. W. R., Mechanism of Crosstalk between the LSD1 Demethylase and HDAC1 Deacetylase in the CoREST Complex. Cell Rep. 2020, 30, 2699-2711.

11. Johnstone, R. W., Histone-deacetylase inhibitors: novel drugs for the treatment of cancer. Nat. Rev. Drug Discov. 2002, 1, 287-299.

12. Falkenberg, K. J.; Johnstone, R. W., Histone deacetylases and their inhibitors in cancer, neurological diseases and immune disorders. Nat. Rev. Drug Discov. 2014, 13, 673-691.

13. Keller, K.; Jung, M., Histone Deacetylase (HDAC) Inhibitors in Recent Clinical Trials for Cancer Therapy. In Epigenetic Therapy of Cancer, Lübbert, M.; Jones, P. A., Eds. Springer: Berlin, Germany, 2014; pp 227-255.

14. Kristensen, H. M. E.; Madsen, A. S.; Olsen, C. A., Inhibitors of the Zinc-Dependent Histone Deacetylases. In Epigenetic Drug Discovery, Sippl, W.; Jung, M., Eds. Wiley-VCH: Weinheim, Germany, 2019; pp 155-184.

15. Mohammad, H. P.; Barbash, O.; Creasy, C. L., Targeting epigenetic modifications in cancer therapy: erasing the roadmap to cancer. Nat. Med. 2019, 25, 403-418. 
16. Jung, M.; Hoffmann, K.; Brosch, G.; Loidl, P., Analogues of trichostatin A and trapoxin B as histone deacetylase inhibitors. Bioorg. Med. Chem. Lett. 1997, 7, 1655-1658.

17. Maolanon, A. R.; Kristensen, H. M. E.; Leman, L. J.; Ghadiri, M. R.; Olsen, C. A., Natural and Synthetic Macrocyclic Inhibitors of the Histone Deacetylase Enzymes. ChemBioChem 2017, $18,5-49$.

18. Montero, A.; Beierle, J. M.; Olsen, C. A.; Ghadiri, M. R., Design, Synthesis, Biological Evaluation, and Structural Characterization of Potent Histone Deacetylase Inhibitors Based on Cyclic alpha/beta-Tetrapeptide Architectures. J. Am. Chem. Soc. 2009, 131, 3033-3041.

19. Deshmukh, P. H.; Schulz-Fademrecht, C.; Procopiou, P. A.; Vigushin, D. A.; Coombes, R. C.; Barrett, A. G. M., Ring-Closing Metathesis in the Synthesis of Biologically Active Peptidomimetics of Apicidin A. Adv. Synth. Catal. 2007, 349, 175-183.

20. Kitir, B.; Maolanon, A. R.; Ohm, R. G.; Colaço, A. R.; Fristrup, P.; Madsen, A. S.; Olsen, C. A., Chemical Editing of Macrocyclic Natural Products and Kinetic Profiling Reveal Slow, Tight-Binding Histone Deacetylase Inhibitors with Picomolar Affinities. Biochemistry 2017, 56, 5134-5146.

21. Elek, G. Z.; Koppel, K.; Zubrytski, D. M.; Konrad, N.; Järving, I.; Lopp, M.; Kananovich, D. G., Divergent Access to Histone Deacetylase Inhibitory Cyclopeptides via a Late-Stage Cyclopropane Ring Cleavage Strategy. Short Synthesis of Chlamydocin. Org. Lett. 2019, 21, 8473-8478.

22. Wang, D.; Helquist, P.; Wiest, O., Zinc Binding in HDAC Inhibitors: a DFT Study. J. Org. Chem. 2007, 72, 5446-5449. 
23. Bondeson, D. P.; Mares, A.; Smith, I. E. D.; Ko, E.; Campos, S.; Miah, A. H.; Mulholland, K. E.; Routly, N.; Buckley, D. L.; Gustafson, J. L.; Zinn, N.; Grandi, P.; Shimamura, S.; Bergamini, G.; Faelth-Savitski, M.; Bantscheff, M.; Cox, C.; Gordon, D. A.; Willard, R. R.; Flanagan, J. J.; Casillas, L. N.; Votta, B. J.; den Besten, W.; Famm, K.; Kruidenier, L.; Carter, P. S.; Harling, J. D.; Churcher, I.; Crews, C. M., Catalytic in vivo protein knockdown by smallmolecule PROTACs. Nat. Chem. Biol. 2015, 11, 611-617.

24. Sakamoto, K. M.; Kim, K. B.; Kumagai, A.; Mercurio, F.; Crews, C. M.; Deshaies, R. J., Protacs: Chimeric molecules that target proteins to the Skp1-Cullin-F box complex for ubiquitination and degradation. Proc. Natl. Acad. Sci. U. S. A. 2001, 98, 8554-8559.

25. Toure, M.; Crews, C. M., Small-Molecule PROTACS: New Approaches to Protein Degradation. Angew. Chem. Int. Ed. 2016, 55, 1966-1973.

26. Burslem, G. M.; Crews, C. M., Proteolysis-Targeting Chimeras as Therapeutics and Tools for Biological Discovery. Cell 2020, 181, 102-114.

27. Schapira, M.; Calabrese, M. F.; Bullock, A. N.; Crews, C. M., Targeted protein degradation: expanding the toolbox. Nat. Rev. Drug Discov. 2019, 18, 949-963.

28. Pettersson, M.; Crews, C. M., PROteolysis TArgeting Chimeras (PROTACs) - Past, present and future. Drug Discov. Today Technol. 2019, 31, 15-27.

29. Naito, M.; Ohoka, N.; Shibata, N.; Tsukumo, Y., Targeted Protein Degradation by Chimeric Small Molecules, PROTACs and SNIPERs. Front. Chem. 2019, 7, 849.

30. An, S.; Fu, L., Small-molecule PROTACs: An emerging and promising approach for the development of targeted therapy drugs. EBioMedicine 2018, 36, 553-562. 
31. Maple, H. J.; Clayden, N.; Baron, A.; Stacey, C.; Felix, R., Developing degraders: principles and perspectives on design and chemical space. Med. Chem. Commun. 2019, 10, 17551764.

32. Vogelmann, A.; Robaa, D.; Sippl, W.; Jung, M., Proteolysis targeting chimeras (PROTACs) for epigenetics research. Curr. Opin. Chem. Biol. 2020, 57, 8-16.

33. Jiang, B.; Wang, E. S.; Donovan, K. A.; Liang, Y.; Fischer, E. S.; Zhang, T.; Gray, N. S., Development of Dual and Selective Degraders of Cyclin-Dependent Kinases 4 and 6. Angew. Chem. Int. Ed. 2019, 58, 6321-6326.

34. Tinworth, C. P.; Lithgow, H.; Dittus, L.; Bassi, Z. I.; Hughes, S. E.; Muelbaier, M.; Dai, H.; Smith, I. E. D.; Kerr, W. J.; Burley, G. A.; Bantscheff, M.; Harling, J. D., PROTAC-Mediated Degradation of Bruton's Tyrosine Kinase Is Inhibited by Covalent Binding. ACS Chem. Biol. 2019, $14,342-347$.

35. Berlin, M.; Crew, A. P.; Crews, C. M.; Dong, H.; Hornberger, K. R.; Wang, J. Modulators of Proteolysis and Associated Methods of Use. WO 2019/195609 A2, 2019.

36. Tovell, H.; Testa, A.; Maniaci, C.; Zhou, H.; Prescott, A. R.; Macartney, T.; Ciulli, A.; Alessi, D. R., Rapid and Reversible Knockdown of Endogenously Tagged Endosomal Proteins via an Optimized HaloPROTAC Degrader. ACS Chem. Biol. 2019, 14, 882-892.

37. Salami, J.; Alabi, S.; Willard, R. R.; Vitale, N. J.; Wang, J.; Dong, H.; Jin, M.; McDonnell, D. P.; Crew, A. P.; Neklesa, T. K.; Crews, C. M., Androgen receptor degradation by the proteolysis-targeting chimera ARCC-4 outperforms enzalutamide in cellular models of prostate cancer drug resistance. Commun. Biol. 2018, 1, 100. 
38. Han, X.; Wang, C.; Qin, C.; Xiang, W.; Fernandez-Salas, E.; Yang, C.-Y.; Wang, M.; Zhao, L.; Xu, T.; Chinnaswamy, K.; Delproposto, J.; Stuckey, J.; Wang, S., Discovery of ARD69 as a Highly Potent Proteolysis Targeting Chimera (PROTAC) Degrader of Androgen Receptor (AR) for the Treatment of Prostate Cancer. J. Med. Chem. 2019, 62, 941-964.

39. Peng, L.; Zhang, Z.; Lei, C.; Li, S.; Zhang, Z.; Ren, X.; Chang, Y.; Zhang, Y.; Xu, Y.; Ding, K., Identification of New Small-Molecule Inducers of Estrogen-related Receptor alpha (ERRalpha) Degradation. ACS Med. Chem. Lett. 2019, 10, 767-772.

40. Zoppi, V.; Hughes, S. J.; Maniaci, C.; Testa, A.; Gmaschitz, T.; Wieshofer, C.; Koegl, M.; Riching, K. M.; Daniels, D. L.; Spallarossa, A.; Ciulli, A., Iterative Design and Optimization of Initially Inactive Proteolysis Targeting Chimeras (PROTACs) Identify VZ185 as a Potent, Fast, and Selective von Hippel-Lindau (VHL) Based Dual Degrader Probe of BRD9 and BRD7.J. Med. Chem. 2019, 62, 699-726.

41. Qin, C.; Hu, Y.; Zhou, B.; Fernandez-Salas, E.; Yang, C.-Y.; Liu, L.; McEachern, D.; Przybranowski, S.; Wang, M.; Stuckey, J.; Meagher, J.; Bai, L.; Chen, Z.; Lin, M.; Yang, J.; Ziazadeh, D. N.; Xu, F.; Hu, J.; Xiang, W.; Huang, L.; Li, S.; Wen, B.; Sun, D.; Wang, S., Discovery of QCA570 as an Exceptionally Potent and Efficacious Proteolysis Targeting Chimera (PROTAC) Degrader of the Bromodomain and Extra-Terminal (BET) Proteins Capable of Inducing Complete and Durable Tumor Regression. J. Med. Chem. 2018, 61, 6685-6704.

42. Winter, G. E.; Buckley, D. L.; Paulk, J.; Roberts, J. M.; Souza, A.; Dhe-Paganon, S.; Bradner, J. E., Phthalimide conjugation as a strategy for in vivo target protein degradation. Science 2015, 348, 1376-1381. 
43. Zengerle, M.; Chan, K.-H.; Ciulli, A., Selective Small Molecule Induced Degradation of the BET Bromodomain Protein BRD4. ACS Chem. Biol. 2015, 10, 1770-1777.

44. Testa, A.; Hughes, S. J.; Lucas, X.; Wright, J. E.; Ciulli, A., Structure-Based Design of a Macrocyclic PROTAC. Angew. Chem. Int. Ed. 2020, 59, 1727-1734.

45. Li, Z.; Lin, Y.; Song, H.; Qin, X.; Yu, Z.; Zhang, Z.; Dong, G.; Li, X.; Shi, X.; Du, L.; Zhao, W.; Li, M., First small-molecule PROTACs for G protein-coupled receptors: inducing alpha1A-adrenergic receptor degradation. Acta Pharm. Sin. B. 2020, in press.

46. Zhou, H.; Bai, L.; Xu, R.; Zhao, Y.; Chen, J.; McEachern, D.; Chinnaswamy, K.; Wen, B.; Dai, L.; Kumar, P.; Yang, C.-Y.; Liu, Z.; Wang, M.; Liu, L.; Meagher, J. L.; Yi, H.; Sun, D.; Stuckey, J. A.; Wang, S., Structure-Based Discovery of SD-36 as a Potent, Selective, and Efficacious PROTAC Degrader of STAT3 Protein. J. Med. Chem. 2019, 62, 11280-11300.

47. Bai, L.; Zhou, H.; Xu, R.; Zhao, Y.; Chinnaswamy, K.; McEachern, D.; Chen, J.; Yang, C.-Y.; Liu, Z.; Wang, M.; Liu, L.; Jiang, H.; Wen, B.; Kumar, P.; Meagher, J. L.; Sun, D.; Stuckey, J. A.; Wang, S., A Potent and Selective Small-Molecule Degrader of STAT3 Achieves Complete Tumor Regression In Vivo. Cancer Cell 2019, 36, 498-511.

48. Steinebach, C.; Kehm, H.; Lindner, S.; Vu, L. P.; Köpff, S.; López Mármol, A.; Weiler, C.; Wagner, K. G.; Reichenzeller, M.; Kronke, J.; Gütschow, M., PROTAC-mediated crosstalk between E3 ligases. Chem. Commun. 2019, 55, 1821-1824.

49. Cromm, P. M.; Samarasinghe, K. T. G.; Hines, J.; Crews, C. M., Addressing KinaseIndependent Functions of Fak via PROTAC-Mediated Degradation. J. Am. Chem. Soc. 2018, 140, 17019-17026. 
50. Hsu, J. H.-R.; Rasmusson, T.; Robinson, J.; Pachl, F.; Read, J.; Kawatkar, S.; O’ Donovan, D. H.; Bagal, S.; Code, E.; Rawlins, P.; Argyrou, A.; Tomlinson, R.; Gao, N.; Zhu, X.; Chiarparin, E.; Jacques, K.; Shen, M.; Woods, H.; Bednarski, E.; Wilson, D. M.; Drew, L.; Castaldi, M. P.; Fawell, S.; Bloecher, A., EED-Targeted PROTACs Degrade EED, EZH2, and SUZ12 in the PRC2 Complex. Cell Chem. Biol. 2020, 27, 41-46.

51. Ottis, P.; Palladino, C.; Thienger, P.; Britschgi, A.; Heichinger, C.; Berrera, M.; JulienLaferriere, A.; Roudnicky, F.; Kam-Thong, T.; Bischoff, J. R.; Martoglio, B.; Pettazzoni, P., Cellular Resistance Mechanisms to Targeted Protein Degradation Converge Toward Impairment of the Engaged Ubiquitin Transfer Pathway. ACS Chem. Biol. 2019, 14, 2215-2223.

52. Zhang, L.; Riley-Gillis, B.; Vijay, P.; Shen, Y., Acquired Resistance to BET-PROTACs (Proteolysis-Targeting Chimeras) Caused by Genomic Alterations in Core Components of E3 Ligase Complexes. Mol. Cancer Ther. 2019, 18, 1302-1311.

53. Schiedel, M.; Herp, D.; Hammelmann, S.; Swyter, S.; Lehotzky, A.; Robaa, D.; Oláh, J.; Ovádi, J.; Sippl, W.; Jung, M., Chemically Induced Degradation of Sirtuin 2 (Sirt2) by a Proteolysis Targeting Chimera (PROTAC) Based on Sirtuin Rearranging Ligands (SirReals). J. Med. Chem. 2018, 61, 482-491.

54. Yang, K.; Song, Y.; Xie, H.; Wu, H.; Wu, Y.-T.; Leisten, E. D.; Tang, W., Development of the first small molecule histone deacetylase 6 (HDAC6) degraders. Bioorg. Med. Chem. Lett. 2018, 28, 2493-2497.

55. Wu, H.; Yang, K.; Zhang, Z.; Leisten, E. D.; Li, Z.; Xie, H.; Liu, J.; Smith, K. A.; Novakova, Z.; Barinka, C.; Tang, W., Development of Multifunctional Histone Deacetylase 6 Degraders with Potent Antimyeloma Activity. J. Med. Chem. 2019, 62, 7042-7057. 
56. An, Z.; Lv, W.; Su, S.; Wu, W.; Rao, Y., Developing potent PROTACs tools for selective degradation of HDAC6 protein. Protein Cell 2019, 10, 606-609.

57. Yang, H.; Lv, W.; He, M.; Deng, H.; Li, H.; Wu, W.; Rao, Y., Plasticity in designing PROTACs for selective and potent degradation of HDAC6. Chem. Commun. 2019, 55, 1484814851.

58. Yang, K.; Wu, H.; Zhang, Z.; Leisten, E. D.; Nie, X.; Liu, B.; Wen, Z.; Zhang, J.; Cunningham, M. D.; Tang, W., Development of Selective Histone Deacetylase 6 (HDAC6) Degraders Recruiting Von Hippel-Lindau (VHL) E3 Ubiquitin Ligase. ACS Med. Chem. Lett. 2020, $11,575-581$.

59. Smalley, J. P.; Adams, G. E.; Millard, C. J.; Song, Y.; Norris, J. K. S.; Schwabe, J. W. R.; Cowley, S. M.; Hodgkinson, J. T., PROTAC-mediated degradation of class I histone deacetylase enzymes in corepressor complexes. Chem. Commun. 2020, 56, 4476-4479.

60. Steinebach, C.; Sosič, I.; Lindner, S.; Bricelj, A.; Kohl, F.; Ng, Y. L. D.; Monschke, M.; Wagner, K. G.; Krönke, J.; Gütschow, M., A MedChem toolbox for cereblon-directed PROTACs. Med. Chem. Commun. 2019, 10, 1037-1041.

61. Tornøe, C. W.; Christensen, C.; Meldal, M., Peptidotriazoles on Solid Phase: [1,2,3]Triazoles by Regiospecific Copper(I)-Catalyzed 1,3-Dipolar Cycloadditions of Terminal Alkynes to Azides. J. Org. Chem. 2002, 67, 3057-3064.

62. Rostovtsev, V. V.; Green, L. G.; Fokin, V. V.; Sharpless, K. B., A Stepwise Huisgen Cycloaddition Process: Copper(I)-Catalyzed Regioselective "Ligation" of Azides and Terminal Alkynes. Angew. Chem. Int. Ed. 2002, 41, 2596-2599. 
63. Kahnberg, P.; Lucke, A. J.; Glenn, M. P.; Boyle, G. M.; Tyndall, J. D.; Parsons, P. G.;

Fairlie, D. P., Design, Synthesis, Potency, and Cytoselectivity of Anticancer Agents Derived by Parallel Synthesis from alpha-Aminosuberic Acid. J. Med. Chem. 2006, 49, 7611-7622.

64. Moreno-Yruela, C.; Vrsanova, A.-E.; Maric, H. M.; Olsen, C. A., Hydroxamic AcidModified Peptide Microarrays for Profiling Isozyme-Selective Interactions and Inhibition of Histone Deacetylases. chemRxiv Preprint. doi.org/10.26434/chemrxiv.11513163.v1.

65. Copeland, R. A., Evaluation of Enzyme Inhibitors in Drug Discovery - A Guide for Medicinal Chemists and Pharmacologists. John Wiley \& Sons: Hoboken, NJ, 2005.

66. Copeland, R. A.; Pompliano, D. L.; Meek, T. D., Drug-target residence time and its implications for lead optimization. Nat. Rev. Drug Discov. 2006, 5, 730-739.

67. Copeland, R. A., The drug-target residence time model: a 10-year retrospective. Nat. Rev. Drug Discov. 2016, 15, 87-95.

68. Obrig, T. G.; Culp, W. J.; McKeehan, W. L.; Hardesty, B., The Mechanism by which Cycloheximide and Related Glutarimide Antibiotics Inhibit Peptide Synthesis on Reticulocyte Ribosomes. J. Biol. Chem. 1971, 246, 174-181.

69. Shanmugasundaram, K.; Shao, P.; Chen, H.; Campos, B.; McHardy, S. F.; Luo, T.; Rao, H., A modular PROTAC design for target destruction using a degradation signal based on a single amino acid. J. Biol. Chem. 2019, 294, 15172-15175.

70. Gadd, M. S.; Testa, A.; Lucas, X.; Chan, K.-H.; Chen, W.; Lamont, D. J.; Zengerle, M.; Ciulli, A., Structural basis of PROTAC cooperative recognition for selective protein degradation. Nat. Chem. Biol. 2017, 13, 514-521. 
71. Bondeson, D. P.; Smith, B. E.; Burslem, G. M.; Buhimschi, A. D.; Hines, J.; JaimeFigueroa, S.; Wang, J.; Hamman, B. D.; Ishchenko, A.; Crews, C. M., Lessons in PROTAC Design from Selective Degradation with a Promiscuous Warhead. Cell Chem. Biol. 2018, 25, 78-87.

72. Adams, J.; Stein, R., Chapter 28. Novel Inhibitors of the Proteasome and Their Therapeutic Use in Inflammation. Annu. Rep. Med. Chem. 1996, 31, 279-288.

73. Cardote, T. A. F.; Ciulli, A., Cyclic and Macrocyclic Peptides as Chemical Tools To Recognise Protein Surfaces and Probe Protein-Protein Interactions. ChemMedChem 2016, 11, 787-794.

74. Sohrabi, C.; Foster, A.; Tavassoli, A., Methods for generating and screening libraries of genetically encoded cyclic peptides in drug discovery. Nat. Rev. Chem. 2020, 4, 90-101.

75. Deyle, K.; Kong, X.-D.; Heinis, C., Phage Selection of Cyclic Peptides for Application in Research and Drug Development. Acc. Chem. Res. 2017, 50, 1866-1874.

76. Simonetti, L.; Ivarsson, Y., Genetically Encoded Cyclic Peptide Phage Display Libraries. ACS Cent. Sci. 2020, 6, 336-338.

77. Rogers, J. M.; Passioura, T.; Suga, H., Nonproteinogenic deep mutational scanning of linear and cyclic peptides. Proc. Natl. Acad. Sci. USA 2018, 115, 10959-10964.

78. Hirose, H.; Tsiamantas, C.; Katoh, T.; Suga, H., In vitro expression of genetically encoded non-standard peptides consisting of exotic amino acid building blocks. Curr. Opin. Biotechnol. 2019, 58, 28-36. 
79. Bashiruddin, N. K.; Nagano, M.; Suga, H., Synthesis of fused tricyclic peptides using a reprogrammed translation system and chemical modification. Bioorg. Chem. 2015, 61, 45-50.

80. Kawakami, T.; Ohta, A.; Ohuchi, M.; Ashigai, H.; Murakami, H.; Suga, H., Diverse backbone-cyclized peptides via codon reprogramming. Nat. Chem. Biol. 2009, 5, 888-890. 